\title{
STANDPOINTS OF EMPLOYEES ABOUT INTRODUCED QUALITY SYSTEMS IN PUBLIC ADMINISTRATION ON THE SAMPLE OF FIVE MUNICIPALITIES OF THE ZENICA-DOBOJ CANTON
}

\author{
Sabahudin Jašarević, Džeraldina Miličević, Samir Lemeš, Safet Brdarević
}

Original scientific paper

Public administration is classified into specific organizational form that follows the development of all civilizations. Today more than ever we deal with creation of a new model of functioning of public administration. What do we need to learn in order to have it more functional and more effective, and accessible to citizens? One of the ways is certainly the introduction of the quality system according to demands of some of the standards such as requirements of ISO 9001 standard. Definitely we have to find the answers to the questions about the possibility of establishing such systems in the units of local self-government, acceptance by employees, understanding of the concept of service in this sector and many other questions. This paper presents a study on a sample of five municipalities in the Federation of Bosnia and Herzegovina, four of which have introduced the quality system. The study included employees who are in direct contact with their customers along with the employees' opinions and standpoints concerning the established quality systems in their environment, as well as questions concerning their knowledge and level of established and introduced quality system through its individual elements. The work is certainly just the beginning on the path of full understanding of quality system in the units of local self-government.

Key words: employees; measurement; public administration; quality; quality system

\section{Stavovi zaposlenika o uvedenim sustavima kvalitete u javnoj upravi na primjeru pet općina Zeničko-dobojskog kantona}

Izvorni znanstveni članak

Javna uprava se svrstava u specifičan organizacijski oblik koji prati razvoj svih civilizacija. Danas se više nego ikad bavimo stvaranjem novog modela funkcioniranja javne uprave. Šta učiti kako bi ista bila funkcionalnija i efektivnija, te dostupna građanima? Jedan od načina je svakako uvođenje sustava kvalitete prema zahtjevima nekih od normi kao što su zahtjevi norme ISO 9001. Svakako da se onda postavljaju pitanja o mogućnosti uspostave ovakvih sustava u jedinicama lokalne samouprave, prihvatanja od strane zaposlenika, razumijevanja pojma usluge u ovom sektoru i brojna druga pitanja. U radu je prikazano istraživanje na primjeru pet općina u Federaciji Bosne i Hercegovine, od kojih četiri imaju uveden sustav kvalitete. U istraživanju su sudjelovali zaposlenici koji su u neposrednom kontaktu s njihovim kupcima te su razmatrana njihova mišljenja i stavovi u vezi izgrađenog sustava kvalitete u njihovim sredinama, kao i pitanja koja se tiču njihovog poznavanja i razine izgrađenog i uvedenog sustava kvalitete kroz njegove pojedine elemente. Rad je svakako tek početak na putu potpunog razumijevanja sustava kvalitete u jedinicama lokalne samouprave.

Ključne riječi: javna administracija; kvaliteta; mjerenje; sustav kvalitete; zaposlenici

\section{Introduction}

Public administration is classified into a specific organizational form that follows the development of all civilizations. Today more than ever we deal with creating a new model of public administration. The reform of public administration wishes to bring a model adjusted to the needs of society, a model based on lawful solutions, real situation and conditions. This process includes principles of the European Charter on Local Self-Government which, among other things, defines governance as the right and the ability of local community to manage important part of public affairs within the boundaries of law.

Public administration reform in Bosnia and Herzegovina is one of the six key priorities of the European Partnership, and the Public administration capable to adopt and implement the acquis communautaire $^{1}$ is one of the most important preconditions for membership in the European Union. Building of administrative capacities, capable to adopt and implement 35 chapters of the EU legislation - is the criterion set to all countries wishing to become members of the Union, in Copenhagen in 1993, and two years later confirmed in Madrid. Obligations of $\mathrm{B} \& \mathrm{H}$ towards the EU are defined through the Stabilisation and Association

\footnotetext{
${ }^{1}$ EU acquis
}

Agreement ${ }^{2}$, whereby the country has committed itself to adopt and implement "legislative, administrative, institutional and economic reforms". Current efforts that are being made in public administration reform will probably have little influence on the actual effect because the focal issues are political and not administrative. [1]

The concept of Public administration - which includes skills, authority, expertise and responsibility - is not understood; valuation principle is not provided for new employees, and employees are insufficiently qualified. The efforts on public administration reform in $\mathrm{B} \& \mathrm{H}$ have little or no political support of local political power and are not successful in solving the acute problems of state administration. [1]

From SIGMA reports, as well as from other reports that treat Public administration in $\mathrm{B} \& \mathrm{H}$, it is clear that Public administration and above all units of local selfgovernment have got distinct characteristics of traditional bureaucracy, including a hierarchical structure, low level of training, poor working culture and the overall orientation towards internal processes rather than focusing towards meeting the needs of all interest groups. It is obvious that the mandate of local government requires

\footnotetext{
2 On 16 June 2008 in Luwembourg Bosnia and Herzegovina signed the Stabilization and Association Agreement (SAA) with the European Union. This was the biggest step towards the membership in this biggest national creation which gathers developed countries of the European continent. After signing the Agreement, the next step is attaining the status of a candidate country for EU membership.
} 
new capacities, attitudes and approaches. This, however, includes the improvement of relations between the municipal council and administration (executive power), between the management (municipal mayor and managerial officials) and executors of the operations (state servants and employees), and between municipalities and interest groups.

Improvement of organizational efficiency in Public administration calls for a paradigm change from the focus towards inwards, bureaucratic systems, processes and standpoints towards new ways of working that put the needs of the public to the fore. [2] The introduction of quality management systems in units of local selfgovernment can serve as a postmodern organizational theory in the context of a broader transformation associated with quality. In this context, quality management basically is seen as a part of cultural revival that will represent a challenge to rigidity of bureaucracy. [3]

At the same time the units of local self-government are facing growing demands and expectations to establish and organize their administration in a way that will allow them to be sensitive to the needs of local communities; improve the culture of public service and accountability of employees; determine and make public the service standards for existing and new services, and become oriented to all interest groups.

Organizational changes mean the changes in the people themselves. The technique of changing the organization comes down to a question how to change people, their attitudes, habits and values, in one word how to change organizational culture. Numerous studies worldwide have shown that structural-functional reforms in administration have significantly less impact if you do not change the type of organizational culture. [4]

In Bosnia and Herzegovina, as well as in neighbouring countries, there are types of organizational culture with a recreative approach. Objectives of servants in such organization are maintaining the current situation, carefully and traditionally performing the tasks and responding only to what cannot be avoided. The servants perform their tasks, as a rule, according to pre-established rules and procedures, and the expectations from employees are clearly defined at the top of the organization, while deviations from the rules are treated as non-functional. This culture is suitable for individuals who prefer safety and order, and for individuals who prefer creativity and innovation it acts as demotivating.

\section{Local self-government}

\subsection{The concept of local self-government}

Local self-government is the common name for various organized ways in which the citizens of local community at their own risk relatively independently regulate public affairs and manage them.

European Charter on Local Self-Government under local government implies the right and the ability of local governments to regulate and manage important share of public affairs in the interest of local inhabitants and at their own risk.

Decision-making and managing the local community is carried out by the members of the community, whether directly or through their representatives they elect. The development of local self-government is one of the conditions of democracy and the rule of law and since the self-government of local communities is usually guaranteed by the Constitution it practically represents an obligation for the State to provide conditions for smooth, continuous functioning of the local community. Its special quality is that performing public affairs enables a citizen an active relation and position to decide or at least influence on deciding about affairs. Therefore, the importance and quality of local self-government is primarily expressed in the possibility of greater articulation of every day's needs and interest of citizens in a way where they become relevant factor of decision-making.

In contrast to the State administration, which is characterized by hierarchical relationship, the subordination of subordinate bodies to higher bodies and centralization in its operation, primary characteristics of local self-government are: autonomy and independence, decentralization and democratization.

\subsubsection{Type of organization of local self-government in Bosnia and Herzegovina}

The Constitution of Bosnia and Herzegovina (Annex 4 of the General Framework Agreement for Peace in $\mathrm{B} \& \mathrm{H}$ - The Dayton Agreement) does not contain provisions on local self-government, except that in the part on territorial organization of Bosnia and Herzegovina, the provision establishing "obligation of entity and all its lower units" [5] defines obligation of all public officials in Bosnia and Herzegovina to adhere to the principles of international law and to respect the Constitution which says "that Bosnia and Herzegovina is a democratic state that operates on the principle of the rule of law and on the basis of free and democratic elections; and that the general principles of international law are a consisting part of the law order of Bosnia and Herzegovina" [6]

Also, there is no law regulating this area on the level of Bosnia and Herzegovina, even though there were advocates to bring the "umbrella" law on Local SelfGovernment. It follows that the local self-government is outside the competence of the state authorities of Bosnia and Herzegovina.

Bosnia and Herzegovina ratified the European Charter of Local Self-Government on 12 July 2002, which was an obligation overtaken by the reception of B\&H into the Council of Europe on April 2002.

The Local self-government in B\&H is developed through two separate and significantly different forms of organization - the one in the Republic of Srpska and the one in the Federation of B\&H. The reason for this is that the entities of Bosnia and Herzegovina are very different, and therefore the local self-government has got different treatment in the Federation of $\mathrm{B} \& \mathrm{H}$ and in the Republic of Srpska. This is reflected in different jurisdictions that constitutions and laws confer on municipalities as units of local self-government, in different level in which municipalities establish trusted power and in different relations of municipalities with higher levels of authority, as well as in different number of levels of authority. 
There are 80 municipalities in the area of the Federation of B\&H and 62 municipalities in the Republic of Srpska. Brčko is a separate administrative unit District. There are currently twelve cities with the status of local self-government in B\&H: Sarajevo, Mostar, Zenica, Tuzla, Bihać and Široki Brijeg in FB\&H and Banja Luka, Istočno Sarajevo, Bijeljina, Doboj, Prijedor and Trebinje in the Republic of Srpska.

\section{The quality in public administration 3.1 Introduction}

Due to the increasing global competition, various actors of society in many countries have begun to put pressure on all aspects of the service sector in order to approach these aspects to the activities of private sector, which is primarily related to higher productivity and efficiency. With the development of the service sector, quality issues were no longer reserved only for production activities. In recent years, the service sector has faced the same problems that the private sector faced in the past. The literature on quality management, when we talk about services, in particular specific part related to public administration, is apparently deprived of an integrated framework that includes all critical dimensions of service quality when we talk about portability of principles and dimensions of quality management systems from production into the service sector, and focusing on dimensions unique for service organizations, and especially for public administration as a specific type of service organizations.

During the 1970 s the significant initiatives were launched with the aim of documenting the productivity of the public sector. Although the concept of quality management was new to the public sector, this does not mean that the public administration in the past was not focused on quality. Quality has always played a role in the public administration, but the meanings have changed over time. Betram distinguishes three phases in the evolution of quality in the public sector: the quality in terms of standards and procedures; the quality in terms of efficiency; and the quality in terms of customer's satisfaction. [7] In the first case, the quality means the absence of arbitrariness or ensuring the safety. In this view, there is a relationship towards user or customer missing. This understanding of quality in the public sector corresponds to the early concept of quality as a matter of technical compliance with the specification in industrial production. In the second case, the meaning of quality in the public sector changed in the late 1960s when the management by objectives gained popularity in the public administration. Quality in the public sphere will always include the absence of procedural errors, but also begins to associate the term of quality with the purpose for which the service should serve. This definition has its equivalent in the famous Juran's definition that the quality is "fitness for use".

From the aspect of actual legislation, especially the Law on Principles of Local Self-Government in the Federation of $\mathrm{B} \& \mathrm{H}$, the picture is mixed. There is visible imbalance in the treatment of principles of user's orientations, effectiveness and efficiency on one hand, and openness, transparency and accountability on the other hand.

Thus, in terms of customer's orientation, effectiveness and efficiency, we can talk about the absence of any policy and any regulation. The law does not refer to the concept of good governance neither explicitly (wording) nor implicitly (by conceptual basis). The law prescribes the jurisdiction of municipalities, but nowhere is insisted on customer's orientation, effectiveness and efficiency, and not the quality of management and service delivery. The first weakness is therefore already in the key law which should regulate the important issues of local government: We cannot expect practical results in terms of the application of the principles and mechanisms of good governance which include customer's orientation and quality, effectiveness and efficiency if the law does not recognize these categories, and certainly does not introduce these principles and mechanisms and prescribes how to monitor and evaluate their implementation. There are no visible signs of changes with other relevant laws, either. In terms of deadlines for processing the cases the law insists only on maximum time allowed to resolve, which is basically the bureaucratic concept of efficiency (when there is the deadline for resolution). Under the new, user-orientated concept, the issues of efficiency become primarily an issue of the speed of service delivery: orientation towards customer seeks as faster service as possible, and statutory deadlines become the only final deadlines that must be met.

Therefore, the perspective almost completely changes: instead of bureaucratic backward looking (by which time the problem, procedure... should be resolved by legal deadlines), we look entrepreneurially forward (when and how quickly we can resolve the problem, procedure, without compromising the validity of the procedure or solution), instead of reactive behaviour characteristic for traditional concept of administration, the modern administration requires proactive behaviour. It is obvious that this is what we might call the official national policy in relation to local government in $\mathrm{B} \& \mathrm{H}$, on the normative level, a number of important principles of good governance is not set as a standard which municipal administrations should achieve. To make matter worse, this policy does not promote nor recommend them. The whole complex of issues related to the promotion and application of the concept of good governance is left to the initiative of municipal administrations and international organizations. As much as it sounds rough, from the analysis of the relevant laws and programs, and the lack of by-laws and recommendations, it can be concluded that the official domestic policy in local administration (and probably in other segments) simply does not know principles of customer's orientation, effectiveness, efficiency and quality. The principles of openness, transparency and accountability are much more promoted and regulated by actual legal solutions. The law on Local Self-Government of RS and the Law on Principles of Local SelfGovernment in the Federation of B\&H (in the draft) regulate almost in details the work of local selfgovernment, including in the term of public work the principles of openness and transparency. Also, further 
issues are processed in details in regard to administrative supervision over the work of local self-government.

A further impetus for the implementation of quality system in the public sector must be provided by the executive authorities (Mayor, Government) in such a way as to ensure efficiency and effectiveness in public services, with a focus on the areas that will jointly contribute to the quality in services. Brysland and Curry identify these areas as follows: [8]

- The quality of communication. Does the municipality communicate, listen and understand service users?

- The quality of specifications. Is this understanding turned into a clear standard for the provision of delivery?

- The quality of delivery. Are the standards respected and are the corrective measures undertaken in case of poor quality of services?

- The quality of people and systems. Are the employees motivated, trained and supported by the good management and system?

According to Chase and Bowen in Hasana and Kerr $(2003: 286)$ the quality of public services can be conceived through the theory of attribution ${ }^{3}$, customer's satisfaction and the theory of interaction. These theories are described as follows:

- The theory of attribution assumes that the quality of services primarily reflects the attributes of the system services, and this applies to the quality of services. The view of the theory of attribution to the quality of services assumes that the management has got significant control over the entrance which defines these attributes.

- The theory of customer's satisfaction defines quality of services as the difference between expected quality of services from perceptions of reality. The theory of customer's satisfaction puts primary importance on the perception of the customer, while the theory of attribution attaches greater importance to the technical aspects of production.

- The theory of interaction defines quality of services as a shared "experience of achievement" of all participants in the public administration.

Marchington (1998:26) classifies the characteristics of services in four categories, such as: intangibility, inseparability, heterogeneity and transience. Intangibility can be defined as the inability to see or touch the "product" of service. Simultaneous production and consumption of service illustrate the characteristics of indivisibility. The heterogeneity can be seen as an implicit lack of consistency, while transience leads to the problem of immediacy of delivery service or lost opportunity of sale. The quality management system is offered as a way for efficiency and changes of organizational culture in the service sector, and thus in the public administration. However, if the quality of services is the foundation of every organizational strategy, there must be a way for its measuring. The focus of such strategy should be on customer and his demands as well as on the process, and analysis of each task/work should be focused on service users, in order to define the requirements.
Curry and Herbert [9] propose considering three categories of quality when it comes to public services. These are: the quality of services intended to users of services and it refers to what the customer wishes as an individual and as a part of the community; professional quality which refers to the proper application of appropriate techniques and procedures necessary to meet the needs of users; the quality of management which included the most effective usage of resources in order to meet the needs of customers. The quality of services provided to the user is provided through measures and techniques designed to customer's satisfaction; professional quality is provided through standard settings and processes and processes of organizational control; and the quality of management refers to development of a holistic approach that includes values and competencies of the concept of quality management into the system.

Therefore, the quality management system includes its role in the whole organization in all activities and relationships. However, the implementation of quality management system requires more than generalities. It requires recognizable set of managing procedures and appropriate methods to prove their effectiveness. Of course, there are the basic assumptions on quality management. Many manuals have pointed out that it is the management philosophy and set of guidelines that organization can use to search for continuous improvement.

\subsection{Specifics of quality in Public Administration}

Large government debt and the associated necessary and unavoidable cost savings, high odds for various benefits, a low opinion of citizens on public administration and a number of other reasons are a starting point in many countries for activities in efforts to "modernize the administration." One part of the modernization of the management board consists of the introduction of a comprehensive quality management. Quality management is a reasonable opportunity to amend the rule of the rule of law as an instrument of governance.

The issue of quality in public administration in general, and therefore in local governments has become one of the subjects significantly present in the literature on public administration in the late 1980s and during 1990 s of the $20^{\text {th }}$ century. Although often mentioned by academics, administrative practitioners, elected officials, the concept of quality is far from simple to define. The literature often points out that it is a term whose definition is "subtle and elusive." [10] Furthermore, it is a dynamic concept that depends on a variety of public interests and standards of different subjects and largely depends on the different perceptions of consumers of services of local governments. Consequently, with the fact that expectations for the quality can vary considerably, and that these may be affected, it is clear that the definition of quality of service in local government is not an easy task because it is influenced by many different, often nonmeasurable factors.

Without some special analysis it is clear that it is much easier to determine the quality when it comes to goods than when it comes to services. It is clear that with "concrete" products there is a material object upon which 
to conduct tests, which can be stored if not in demand, etc., while it is not the case when we talk about services. Furthermore, the services provided by local governments are more specific in relation to the services provided by service companies from a profit sector. Namely, the possibility of determining the quality level is very difficult because the services are provided immediately, at the place of origin. A powerful mechanism of the market, based on supply and demand, with the existence of competition, does not exist and is not applicable when it comes to public administration services, and this ability to choose is one of the best indicators of quality of service in the private sector.

In contrast to the private sector, in the public administration there is no market mechanisms that would impose quality as a prerequisite for survival in the market. This is one reason why the spirit of entrepreneurship cannot "put down roots" in public administration at any level. The fact is that certain services are provided because it is considered to be socially useful, without the real profitability of their performance. Today there is a tendency to believe that the public administration is inefficient, and accordingly is increasingly losing the trust of society.

Very often it is observed and exaggerated when it comes to mistakes committed by public administration. A characteristic example of this is that if the customer is treated in an inappropriate way, or not satisfied with the product of some company, as a rule, it will not generalize such neglect or mistake as a failure or the poor performance of the whole manufacturing industry, or even of all production companies. However, exactly such a generalization is almost the rule, when it comes to the failure of public administration at any level. On the other hand, this is not so illogical, given that citizens partly finance the public administration through various fees, taxes and contributions. Because of this phenomenon, which significantly affects the image of public administration as a whole, each local government must strive for impeccable organization and quality of its services, not only because of its image and reputation but also the reputation of the entire public administration at all levels, because each positive and negative effect is reflected in other units of local government, as well as higher levels of government.

Below there are presented some typical statements and comments related to the ratio of the quality system and bureaucracy [11]:

a) "Politics is like war. Winners do not recognize programs of defeated even if they are perfectly good and applicable" [12]; Many newly elected politicians in most cases negate the achievements and successful programs of its predecessors. The new administration would rather start again than to continue where their predecessors left off.

b) "Improving the quality and policies does not go together very well" [12]; This does not mean that they do not go together, but it indicates that this process is very difficult. Politicians in our country and in the world generally are elected for a term of four years, and somewhere even of two years. It is understandable that the quality system simply will not give the right results in such a short time. Politicians as top management would have to think of quality system with the idea of long-term value for the state, the city, the citizens.

c) "If we leave them alone, the administrations will try to keep the present status at the expense of new ideas and new ways of working" [12]; Maintaining the status quo at the expense of improvements and organizational changes is the boldest inner strength that will resist to any new ideas and change. Although many problems can be easily overcome with new ideas, visions, well-defined missions, teamwork, innovations, the bureaucracy rather keeps on "wellestablished" mode. Yet it should be noted that the changes are the part of the work of management, not the workers, the workers always think they work well.

d) "The greatest damage to the quality management within the state and local administration stems from the so-called Cowboy Management "(adapted from [12]; The philosophy of a cowboy comes from the fact that cowboys work alone, quickly, they are independent, macho, quiet and always know what to do. That's the biggest damage for the successful implementation of quality systems. Cowboy management easily denies teamwork which is the basic prerequisite for the introduction of quality systems. The second major obstacle to the introduction of TQM in local administrations stems from our own ego, from our own I instead of US/WE and philosophy that the individual is better and more important than the team.

The value of ISO 9001 lies in the fact that it can be applied to all types of organizations, from the production companies to municipal or cantonal administration, in other words, from profit to non-profit organizations, as well as those that represent an international orientation.

It should be also noted that the majority of experts for the quality agree that the application of ISO 9000 represents only a basic level of quality systems, with a warning that the application is not a guarantee of quality. Even it can be said that the implementation of quality systems according to ISO 9001: 2008 represents only a starting point in the implementation of a more complex system for quality management.

\subsection{The concept of Service in public sector}

Public administrations, and therefore the local selfgovernments almost completely and only provide the services. Therefore, the translation of the concept of quality management and the spirit of ISO standards in public administration is somewhat more demanding.

This complexity stems primarily from the fundamental differences between the services and products, and some of the criteria according to which a distinction is made are as follows: [13]

- The needs of users,

- Intangibility product,

- The order of production and consumption (which in the case of services most likely occur at the same time)

- The presence/absence of the user, 
- $\quad$ The share of the labour/capital

The sustainability of the results,

Persistence of quality.

The fact is that the quality of offered service usually almost entirely depends on who provides it, and his competence, physical and mental state are often critical to the quality of services.

The product is in standard ISO 9000:2005 "Fundamentals and vocabulary" defined as: "The result of a set of interrelated or interactive activities that transform inputs into outputs". This definition is sufficiently wide and general that it gives space for the proper interpretation in the implementation of quality standards in any field, including public administration, where the task is to determine what the product is that is a result of its work processes and who is being offered user.

The product of public administration - public services - is a term usually used to mean services provided by public administration, or local self-government as part of it, to its citizens. Public services are considered to be those services that are essential to the functioning of modern society, so that the reasons have to impose their universal availability to all citizens, which is why one part can be subsumed under the category of human rights. Public services can sometimes have the characteristics of a public good, given their lack of competitiveness and non-excludability, but are generally a good service to the services that the prevailing social norms are considered under-represented in the market. [14]

The concept of quality in the public sector has a different context from the one in the private sector. When talking about the product of public administration - the service, we actually refer to "everyday procedures and services whose characteristics are credibility, readiness, response, integrity, efficiency and flexibility." [15]

\subsection{Who is "the customer" in Public Administration}

As there is a difference in the concept of services provided in the public and private sectors, so there is a significant difference between the concept of a customer. Also, the meaning of one of the priority categories, i.e. requires "customer satisfaction" is also significantly different. Namely, the buyer in the public administration is primarily (but not only) a citizen, who establishes different relations with the unit of local self-government, with different and complex roles, depending on the situation. Situation, again, can be very different, even conflicting. In some, the citizen-customer will require the realization of his rights, and in the other, his interest will be his local self-governments to provide a service. For example, a citizen in one case may be the classic customer who requires a certain service, and in the second case submits the request for the issuance of certain permits, which must meet the requirements (required by law) imposed by the service provider and there is no choice. Citizen, for example the owner of a business who is the subject of any inspections is certainly not the customer of services of the local government, nor he feels it in that sense. Can we talk about the customer or his satisfaction in the situation of eviction, having passed the Law on Restitution, Allocation and Sale of Apartments and ceased to exist institute alternative accommodation, a civil servant delivered his "services" perfectly in accordance with the law. Of course, these are extreme cases, where the author does not intend to prove the inadequacy of the introduction of quality systems, but only that the services of public administration, and local self-governments as well as its exponent are very complex and involve conflicting roles and interests, and that this should be paid great attention to, especially in light of the determination of the organization's objectives.

However, even the concept of the citizen as a consumer of public services is too narrow and does not correspond to the concept of citizenship of modern liberal democracy. The citizens of modern democracies are not only consumers of public services but also members of a political community with specific civil rights and obligations. These rights are largely related to public administration, according to which citizens make demands that the administration should respect and fulfill. The concept of citizenship has a connotation of activities and stands in contradiction to the passive concept of consumer, i.e. consumer of services in the private sector. The buyer has no obligation to the service provider, the citizen has. Citizenship implies collective action of individuals to achieve a common goal, while the concept of consumer is largely individual. The consumer is interested in efficiency and market competition, which lowers the price of services, while citizens, primarily through the work of the public administration, are interested in values such as social justice, participation of different social groups, including marginalized participation in decision-making, impartiality, equality, the rule of law, the responsibility of the administration before the democratic public and others.

In order to achieve their rights and make impact on improving quality of services, citizens must use formal and informal methods of pressure (media, petitions, initiatives, debates, etc.), while in contrast beneficiaries in the private sector can be absolutely indifferent to the streams of quality in a private company because it will be done for them by the market mechanism. If the citizen is dissatisfied with the service in the private sector, he will simply look for the service and get it from another service provider, until he finds a service that fully meets his requirements, and service providers in turn, must take into account the quality and customer's satisfaction because it is a requirement for their survival in the market. Furthermore, certain services have a monopoly position in the public sector however, and there is no excessive tendency to increase the level of quality of their services. [16]

The quality management system through the principle of "focus on customer" is fully in line with the belief that the administration exists for the people, for its citizens, and that it represents their rights and interests, and is not an obstacle to the achievement of the various interests that occur in a number of situations in which there are citizens as customers of local self-governments. Achieving the "customer satisfaction" is also feasible by introducing and implementing the quality system, which can help identify these various interests, i.e. interest groups by its systematic approach and requirements. It was the interest groups, or even better the interest partners that are the best synonym for the customer when it comes to public 
administration, i.e. local self-governments. The main objective to be achieved through the implementation of quality systems in the units of local self-government is meeting the requirements and expectations of customers interest partners, such as (Fig. 1):

- Citizens (satisfactory quality of service, the implementation of investment, better quality of life)

- Employees (satisfaction with the work and career)

- Suppliers (lasting business relationship)

- $\quad$ Society (responsible business)

- $\quad$ The private sector (business friendly environment).

Here we observe similarity with stakeholder approach, which is a useful way to identify and understand the different types of interests of all interested parties of an organization. [17]

The main idea is the notion that the administration exists for the people, for its citizens, and that it represents their rights and interests. When it is very well understood, repeated hundreds of times and safe, only then the introducing of quality system can be successful.

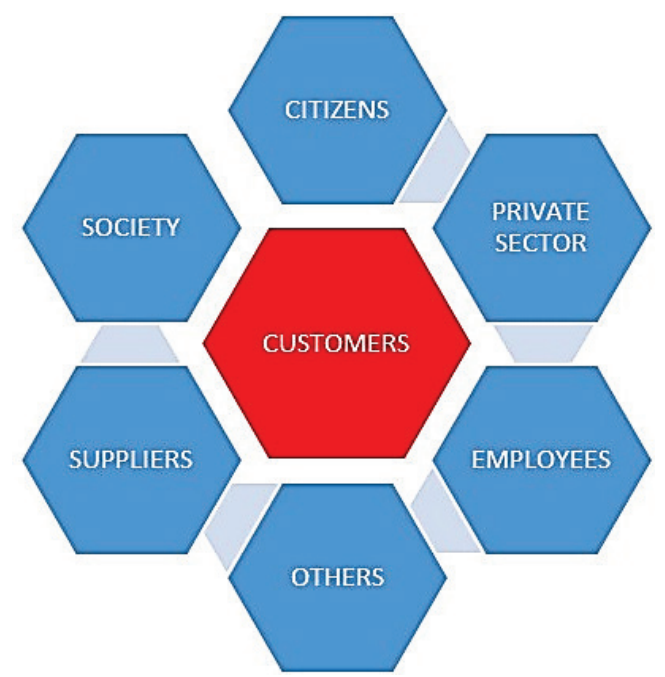

Figure 1 The concept of Customer in Public Administration

\section{Measuring of quality in Public Administration}

Measuring of quality must take into account many influences and blends of different values, expectations, conflicting requirements. Additional problems come to the surface, and they are inherent in a democratic political structure of the country. Because of this complexity, which follows the efforts of measuring quality, there are no uniform methods of measurement, but is seeking to establish various parameters, which along with quantitative, try to include qualitative indicators too.

Many countries apply a methodology for measuring the results and effectiveness of certain segments of operation of public administration, such as for example the public expenditure. Their experiences show that the application of the methodology and monitoring the achieved results and the efficiency result in reduced public spending and/or increasing results in the public sector. In addition to the improvement of budget planning, especially budgetary spending, monitoring of expected results and effects of public money are the subject of much analysis and debate, they are also listed an important priority in a number of strategic documents concerning the management of budgets at all levels, from national to the local. The practice has not established the methodology for measuring results and effectiveness of public administration. Also, there is no system of indicators that would allow measurement of the effectiveness of public service delivery, and there are no performance indicators which would allow monitoring of the results achieved and effects.

In Bosnia and Herzegovina there is no available data for precise measuring of results and effectiveness of the public administration, nor even the basic data on the size and basic characteristics of public administration at different levels of authority. Evaluating the effectiveness of public administration in Bosnia and Herzegovina on the basis of indicators used in the economic literature shows that public administration achieves significantly worse results compared to countries in the immediate environment, particularly in relation to the EU countries.

More efficient public administration would mean greater capacity and accountability of public administration in the use of resources for the realization of the planned objectives and priorities, which could influence the reduction of public spending and/or increasing the performance of the planned objectives. Improvement of performance and efficiency of public administration is also important because of the impact that public administration has to other aspects of the overall quality of life. Public administration in Bosnia and Herzegovina must accept common European standards of transparency, efficiency, accountability and compliance. They are indicators of efficient and effective public sector that provides quality services to its citizens and continually seeks to protect the constitutional rights, strengthen democracy and enable progress and prosperity through sustainable development.

\section{Research/Survey}

The aim of the study was to try to get the answers to the questions among the employees in the public administration, on how they see some of the elements of quality systems in their communities. The survey was carried out in five municipalities of the Zenica-Doboj Canton: Zavidovići, Žepče, Maglaj, Kakanj and Vareš, including civil servants and employees and mayors, sample of $20 \%$ or 100 respondents in five municipalities. We used such a high percentage of a representative sample because of uneven structure of employees, with a fact that the majority of employees in municipalities in $\mathrm{BiH}$, according to available data, are with secondary education. The survey was conducted through a questionnaire.

We sent 20 questionnaires in each of aforementioned municipalities, in total 100 questionnaires, and there were 80 returned, meaning $80 \%$, which indicates that the respondents showed interest in the subject matter, while smaller part did not show interest for involvement in the study. The highest return was from the Municipality of Zavidovići (100\%), and the lowest from the Municipality of Žepče $(65 \%)$. [18] 


\subsection{Structure of respondents}

Tabs. 1-3 show the structure of respondents according to different criteria, of gender, age, working experience.
We wanted to have different groups in this research and we hope we succeeded, and it is presented in the following tables.

Table 1 Gender structure of respondents [18]

\begin{tabular}{|c|l|c|c|c|c|}
\hline No. & \multicolumn{1}{|c|}{ Municipality } & Male & Percentage (\%) & Female & Percentage (\%) \\
\hline 1 & Zavidovići & 10 & 50 & 10 & 50 \\
\hline 2 & Kakanj & 6 & 33,33 & 12 & 66,67 \\
\hline 3 & Žepče & 7 & 46,67 & 8 & 53,33 \\
\hline 4 & Vareš & 9 & 69,23 & 4 & 30,77 \\
\hline 5 & Maglaj & 6 & 42,86 & 8 & 57,14 \\
\hline \multicolumn{2}{r|r|}{ Total: } & 38 & 47,50 & 42 & 52,50 \\
\hline
\end{tabular}

Table 2 Age structure of respondents [18]

\begin{tabular}{|c|c|c|c|c|c|c|c|c|c|c|c|}
\hline \multirow[b]{2}{*}{ No. } & \multirow[b]{2}{*}{ Municipality } & \multicolumn{10}{|c|}{ Age } \\
\hline & & $18 \div 30$ & $\%$ & $31 \div 40$ & $\%$ & $41 \div 50$ & $\%$ & $51 \div 60$ & $\%$ & $>60$ & $\%$ \\
\hline 1 & Zavidovići & 1 & 5,00 & 5 & 25,00 & 6 & 30,00 & 7 & 35,00 & 1 & 5,00 \\
\hline 2 & Kakanj & 1 & 5,56 & 7 & 38,89 & 3 & 16,67 & 6 & 33,33 & 1 & 5,56 \\
\hline 3 & Žepče & 5 & 33,33 & 2 & 13,33 & 2 & 13,33 & 5 & 33,33 & 1 & 6,67 \\
\hline 4 & Vareš & 2 & 15,39 & 4 & 30,80 & 2 & 15,38 & 4 & 30,80 & 1 & 7,69 \\
\hline 5 & Maglaj & 1 & 7,14 & 3 & 21,43 & 6 & 42,86 & 3 & 21,43 & 1 & 7,14 \\
\hline & Total: & 10 & 12,50 & 21 & 26,25 & 19 & 23,75 & 25 & 31,25 & 5 & 6,25 \\
\hline
\end{tabular}

Table 3 Structure of respondents in accordance with the working experience [18]

\begin{tabular}{|c|c|c|c|c|c|c|c|c|c|c|c|}
\hline \multirow{2}{*}{ No. } & \multirow{2}{*}{ Municipality } & \multicolumn{10}{|c|}{ Working experience (years) } \\
\hline & & $<5$ & $\%$ & $6 \div 10$ & $\%$ & $11 \div 20$ & $\%$ & $21 \div 30$ & $\%$ & $31 \div 40$ & $\%$ \\
\hline 1 & Zavidovići & 1 & 5 & 3 & 15 & 2 & 10 & 9 & 45 & 5 & 25 \\
\hline 2 & Kakanj & 2 & 11,11 & 5 & 27,78 & 4 & 22,22 & 4 & 22,22 & 3 & 15 \\
\hline 3 & Žepče & 4 & 26,67 & 2 & 13,33 & 2 & 13,33 & 2 & 13,33 & 5 & 33,33 \\
\hline 4 & Vareš & 4 & 38,46 & 2 & 15,38 & 2 & 15,38 & 4 & 38,46 & 1 & 7,69 \\
\hline 5 & Maglaj & 1 & 7,14 & 2 & 14,29 & 5 & 35,71 & 3 & 21,43 & 3 & 21,43 \\
\hline & Total: & 12 & $15 \%$ & 14 & $17,5 \%$ & 15 & $18,75 \%$ & 22 & $27,5 \%$ & 17 & $21,25 \%$ \\
\hline
\end{tabular}

\section{Results of research}

The first group of questions are those related to quality systems, their introduction, implementation, training, etc. (Tabs. $4 \div 12$ ), while the second group of questions will relate to the quality tools used in the services and for the improvement of the quality system (Tabs. $13 \div 15$ )

\subsection{Questions on Quality Management System}

After conducting the interviews and questionnaires with mayors, and based on available public information, municipalities are subjected to testing and certified for the following standards: Municipality Zavidovići Integrated Quality System ISO 9001:2008 and ISO 14001:2004, the municipality of Kakanj, Žepče and Vareš ISO 9001:2008, while the Municipality of Maglaj has not introduced the quality management system.

Informing the staff about the type of certificate that their municipality has is generally unsatisfactory, according to the results of this question. Namely, in the municipality of Zavidovići all employees, it is true, know that they have introduced quality management system, but confusion is noticeable about which standards are functioning, so $55,00 \%$ say that it is ISO 9001:2008, $35,00 \%$ say it is ISO 14001:2004, and only 10,00\% answered correctly that it is an integrated system of quality management. In the municipality of Kakanj 88,89 $\%$ of respondents answered correctly, while $11,12 \%$ of respondents do not know which certificate the municipality has got, and 5,56\% does not even know that they have introduced the quality management system. In the municipality of Žepče the situation is worse, where even $26,67 \%$, i.e. nearly a third of employees do not even know that they have introduced the quality management system, and 73,33\% answered correctly. In the municipality of Vareš is a similar situation, where 15,38 $\%$ of respondents mistakenly believe that the municipality introduced a system of environmental management, while $84,62 \%$ gave correct answers (Tab. 4).

Table 4 Is the quality management system in your municipality certified according to some of the standards [18]

\begin{tabular}{|c|c|c|c|c|c|}
\hline STATEMENT & Zavidovići, \% & Kakanj, \% & Žepče, \% & Vareš, \% & Maglaj, $\%$ \\
\hline ISO 9001:2008 & 55,00 & 88,89 & 73,33 & 84,62 & $x$ \\
\hline ISO 14001:2004 & 35,00 & 0,00 & 0,00 & 15,38 & $\times$ \\
\hline Integrated Quality System ISO 9001:2008 and ISO 14001:2004 & 10,00 & 5,56 & 0,00 & 0,00 & $\times$ \\
\hline Nothing from above & 0,00 & 5,56 & 26,67 & 0,00 & $\times$ \\
\hline
\end{tabular}

These responses suggest that the awareness of employees about the quality management system is insufficient, which may indicate, besides these external manifestations, of not fulfilling the group of requirements 5. The commitment of the leadership to a present problem of apparent implementation of quality management systems in order to obtain "political points "for certificates, with no real intent to make it rise, but also a tool for a more or less radical organizational changes and improving the quality of services provided by local governments. 
Table 5 According to Your opinion do you think that the quality management system is successfully applied in your Municipality? [18]

\begin{tabular}{|l|c|c|c|c|c|}
\hline \multicolumn{1}{|c|}{ STATEMENT } & Zavidovići (\%) & Kakanj (\%) & Žepče (\%) & Vareš (\%) & Maglaj (\%) \\
\hline Yes & 5,00 & 27,78 & 33,33 & 15,38 & $\times$ \\
\hline No & 20,00 & 5,56 & 6,67 & 7,69 & $\times$ \\
\hline Partly & 70,00 & 38,89 & 53,33 & 76,92 & $\times$ \\
\hline I don't know & 5,00 & 27,78 & 6,67 & 0,00 & $\times$ \\
\hline
\end{tabular}

Respondents in all municipalities that were the subject of research believe that the quality system in their municipality is partially applied: Zavidovići 70,00\%, Kakanj 38,89 \%, Žepče 53,33 \% and Vareš 76,92 \%, indicating that employees are aware that there is still room and need for activities on the application of the quality management system. (Tab. 5)

Table 6 Have you got a training for the quality management? [18]

\begin{tabular}{|lc|c|c|c|c|c|}
\hline & STATEMENT & Zavidovići (\%) & Kakanj (\%) & Žepče (\%) & Varěs (\%) & Maglaj (\%) \\
\hline Yes, regularly & 10 & 16,67 & 20,00 & 0,00 & $\times$ \\
\hline Rarely & 75 & 55,56 & 53,33 & 76,93 & $\times$ \\
\hline No & 15 & 27,78 & 26,67 & 23,08 & $\times$ \\
\hline
\end{tabular}

Training in the field of quality management is carried out rarely, which was confirmed by the majority of respondents in all municipalities: Zavidovići $75 \%$, Kakanj 55,56 \%, Žepče 53,33 \% and Vareš 76,93 \%, with a significant percentage is not at all involved in the process training: Zavidovići $15 \%$, Kakanj 27,78 \%, Žepče 26,67 \% and Vareš 23,08 \%. This again points out, in addition to failing to meet group requirements 6 . Human resources, to the lack of commitment of the leadership (group of statements 8). (Tab. 6)

In the municipalities of Zavidovići (35\%) and Kakanj $(44,44 \%)$ internal training is mainly carried out on the topic of quality management, while in the
Municipality of Žepče (33,33 \%) employees are educated to work in teams and in Vareš there was even $46,15 \%$ respondents answering that there was no internal training carried out. A relatively high percentage of respondents in other municipalities stated that internal training is not conducted, in Zavidovići $30 \%$ and Kakanj 27,78\%, Žepče $20,00 \%$. A very small percentage, except in Zavidovići $(15,00 \%)$ stated internal audit as a topic of internal education, which means that they do not analyse the mistakes made or identified areas for improvement. It is obvious that it does not pay enough attention to education of employees, especially in order to improve work processes and organizational culture. (Tab. 7)

Table 7 Mark the topics represented in your internal education (internal training) in your Municipality [18]

\begin{tabular}{|c|c|c|c|c|c|}
\hline STATEMENT & Zavidovići (\%) & Kakanj (\%) & Žepče (\%) & Vareš (\%) & Maglaj (\%) \\
\hline Quality management System & 35 & 44,44 & 13,33 & 23,08 & $\times$ \\
\hline Organizational culture & 10 & 5,56 & 6,67 & 7,69 & $\times$ \\
\hline Team work & 0 & 5,56 & 33,33 & 7,69 & $\times$ \\
\hline Tools for resolving the problems and conflicts & 5 & 0,00 & 13,33 & 0,00 & $x$ \\
\hline Results of Internal audits & 15 & 5,56 & 13,33 & 7,69 & $x$ \\
\hline Nothing from above & 5 & 11,11 & 0,00 & 7,69 & $x$ \\
\hline We do not carry out internal training/education & 30 & 27,78 & 20,00 & 46,15 & $x$ \\
\hline
\end{tabular}

Table 8 Mark which documents your Municipality has got [18]

\begin{tabular}{|c|c|c|c|c|c|}
\hline STATEMENT & Zavidovići (\%) & Kakanj (\%) & Žepče (\%) & Vareš (\%) & Maglaj (\%) \\
\hline Vision & 15 & 44,44 & 33,33 & 84,62 & $x$ \\
\hline Mission & 10 & 50,00 & 26,67 & 84,62 & $x$ \\
\hline Policy of the quality & 95 & 55,56 & 60,00 & 92,31 & $x$ \\
\hline Code of Conduct & 70 & 50,00 & 53,33 & 53,85 & $x$ \\
\hline Etical Code & 60 & 66,67 & 80,00 & 53,85 & $x$ \\
\hline I don't know & 0 & 11,11 & 6,67 & 0,00 & $x$ \\
\hline
\end{tabular}

The answer to this question points to a lack of awareness and education of the employees about the documents in their possession, as well as on the content of documents quality. This conclusion derives from nonuniformity of answers. Specifically, in Zavidovići $95 \%$ of employees know that they have the quality policy, but that they have the vision and mission there are only $15 \%$ and $10 \%$ of respondents. It is very difficult to expect a commitment to the vision and mission of the organization when $85 \div 90 \%$ of the respondents do not even know that they exist. In Kakanj 55,56 \% of respondents know that they have a quality policy and about the same number knew of the existence of the vision and mission. Unsatisfactory is the fact that almost half of the respondents do not have this knowledge. In Žepče 60,00 $\%$ know about the quality policy, and $26,67 \%$ about the mission, and $33,33 \%$ about the vision of the organization. In Vareš, the situation is the best in this regard. Here is $92,31 \%$ of the respondents knowing about owning the Quality Policy, and almost the same number knew about the vision and mission of the organization. Answers to this question suggest the need for better communication, education on quality management system and document quality, and for the success of this part also there is necessary commitment of leadership. (Tab. 8)

In most municipalities employees are not familiar with whether new employees receive information on the management system - Zavidovići $65 \%$, Kakanj 55,56\% and Vareš $61,54 \%$, while in Žepče equal number of staff is familiar and not familiar with the above practices (46,67\%). (Tab. 9) 
Table 9 During hiring new employees and civil servants, do they get information on the Quality Management System? [18]

\begin{tabular}{|c|c|c|c|c|c|}
\hline STATEMENT & Zavidovići (\%) & Kakanj (\%) & Žepče (\%) & Vareš (\%) & Maglaj (\%) \\
\hline Yes & 25 & 16,67 & 46,67 & 7,69 & $x$ \\
\hline We work in accordance with the law & 10 & 27,78 & 6,67 & 30,77 & $x$ \\
\hline I don't know & 65 & 55,56 & 46,67 & 61,54 & $x$ \\
\hline
\end{tabular}

Table 10 Do you think that the quality culture is the same as the organizational culture? [18]

\begin{tabular}{|c|c|c|c|c|c|}
\hline STATEMENT & Zavidovići (\%) & Kakanj (\%) & Žepče (\%) & Vareš (\%) & Maglaj (\%) \\
\hline Yes & 40 & 38,89 & 46,67 & 69,23 & 0 \\
\hline We work in accordance with the law & 60 & 66,67 & 46,67 & 30,77 & 0 \\
\hline I don't know & 0 & 0,00 & 6,67 & 0,00 & 0 \\
\hline
\end{tabular}

The largest number of respondents varies in quality culture and organizational culture - Zavidovići and Kakanj 50,00 \%, Žepče $60,00 \%$ and Vareš $69,23 \%$, indicating a good basis for further education of employees. (Tab. 10)

Answers to the question on mutual respect and openness indicate a low level of organizational culture, but the culture of quality, with the exception of the Municipality of Kakanj, where 72,22 \% said that mutual respect and openness are reported extensively. The worst results are in the municipality of Zavidovići where $80 \%$ of respondents said that mutual respect and openness are reported on a small scale, followed by the municipality of Vareš, where this standpoint has $46,15 \%$ of respondents, with an additional $23,08 \%$ of respondents who believe that respect and openness were not displayed at all. In the
Municipality of Žepče almost the same number of respondents believe that the respect and openness are stated in a large $(46,67 \%)$ and small $(40,00 \%)$ measure/scale. (Tab. 11)

When asked about the focus on customer satisfaction, respondents (in Zavidovići $(60,00 \%)$ and Kakanj $(66,67 \%)$ said they were working in accordance with the law, which despite the introduction of the quality system indicates the existence of bureaucratic ways of doing business and the perception of the parties. In Žepče the same number of respondents argued that they are focused on customer satisfaction, i.e. to work in accordance with the law. In Vareš is the largest number of respondents that said that they are focused on customer satisfaction 69,23 \%. (Tab. 12)

Table 11 To what extent/scale do employees in your municipality show mutual respect and opened during their work?[18]

\begin{tabular}{|l|c|c|c|c|c|}
\hline \multicolumn{1}{|c|}{ STATEMENT } & Zavidovići (\%) & Kakanj (\%) & Žepče (\%) & Vareš (\%) & Maglaj (\%) \\
\hline On a large scale & 10 & 72,22 & 46,67 & 7,69 & 0 \\
\hline On a small scale & 80 & 27,78 & 40,00 & 46,15 & 0 \\
\hline Not at all & 5 & 0,00 & 13,33 & 23,08 & 0 \\
\hline I don't know & 5 & 0,00 & 0,00 & 23,08 & 0 \\
\hline
\end{tabular}

Table 12 Are you focused to the satisfaction of a customer (party)? [18]

\begin{tabular}{|l|c|c|c|c|c|}
\hline \multicolumn{1}{|c|}{ STATEMENT } & Zavidovići (\%) & Kakanj (\%) & Žepče (\%) & Vareš (\%) & Maglaj (\%) \\
\hline Yes & 40 & 38,89 & 46,67 & 69,23 & 0 \\
\hline We work in accordance with the law & 60 & 66,67 & 46,67 & 30,77 & 0 \\
\hline I don't know & 0 & 0,00 & 6,67 & 0,00 & 0 \\
\hline
\end{tabular}

\subsection{Questions on the tools of Quality Management System}

When it comes to encouraging creativity and innovation, and the initiative from the staff the situation is not satisfactory as in most municipalities respondents answered NO to the question whether they are encouraged to submit proposals for improving the working process 95,00 \% of Zavidovići, Kakanj 77,78 \% , Vareš 69,23\% and $92,86 \%$ Maglaj, while the majority of respondents answered positively only in the municipality of Žepče $60,00 \%$. (Tab. 13)

To the question of rewarding for a job well done the majority of respondents replied negatively in municipalities of Zavidovići $65 \%$, Žepče 53,33 \%, Vareš 92,31 \% and Maglaj 64,29 \%, while in Kakanj 38,89 \% of respondents answered negatively, and 27,78\% answered that rewards go to similar persons, but not to the capable ones. This response was given by $25 \%$ of respondents in Zavidovići, 13,33 \% in Žepče and 35,71 \% in Maglaj, while a smaller number of respondents 7,69\% have this standpoint in Vareš. Positive answer gave $10 \%$ of respondents in Zavidovići and 33,33 \% in Kakanj and Žepče, while no one in Vareš and Maglaj responded positively (Tab. 14) .

Table 13 Are you encouraged to submit proposals for improvement of the working process? Have you got a box/book or a place for submitting proposals? [18]

\begin{tabular}{|c|c|c|c|c|c|}
\hline STATEMENT & Zavidovići (\%) & Kakanj (\%) & Žepče (\%) & Vareš & Maglaj (\%) \\
\hline YES & 5 & 22,22 & 60 & 30,77 & 7,14 \\
\hline $\mathrm{NO}$ & 95 & 77,78 & 40 & 69,23 & 92,86 \\
\hline
\end{tabular}

Table 14 Have you received a reward or recognition for a job well done? [18]

\begin{tabular}{|c|c|c|c|c|c|}
\hline STATEMENT & Zavidovići (\%) & Kakanj (\%) & Žepče $(\%)$ & Vareš (\%) & Maglaj (\%) \\
\hline YES & 10 & 33,33 & 33,33 & 0 & 0 \\
\hline Rewards go to the similar persons but not to the capable persons & 25 & 27,78 & 13,33 & 7,69 & 35,71 \\
\hline $\mathrm{NO}$ & 65 & 38,89 & 53,33 & 92,31 & 64,29 \\
\hline
\end{tabular}


The structure of the response indicates that in the units of local self-government that were subject of this research the motivation is completely neglected, so the employees are not rewarded for their achievements or, even worse, are rewarded for the wrong reasons (similar persons).

Customer's satisfaction surveys are carried out sometimes in Kakanj (50 \%), Žepče $(66,67 \%)$ and Vareš
$(76,92 \%)$, while in Zavidovići they are carried out rarely $(45 \%)$. These results indicate the lack of a genuine desire to obtain feedback from users/customers on satisfaction to these services, i.e. the lack of a genuine commitment to customer's satisfaction, as well as the lack of management commitment to the effective implementation of quality systems in units of local self-government. (Tab. 15)

Table 15 How often are there surveys on customer's satisfaction? [18]

\begin{tabular}{|c|c|c|c|c|c|}
\hline STATEMENT & Zavidovići (\%) & Kakanj (\%) & Žepče (\%) & Vareš (\%) & Maglaj (\%) \\
\hline Regularly & 0 & 5,56 & 13,33 & 0 & 0 \\
\hline Often & 5 & 11,11 & 0 & 0 & 0 \\
\hline Sometimes & 25 & 50 & 66,67 & 76,92 & 0 \\
\hline Rarely & 45 & 27,78 & 6,67 & 15,38 & 0 \\
\hline Never & 20 & 5,56 & 6,67 & 0 & 0 \\
\hline Survey has been carried out, but not analysed & 5 & & 6,67 & 7,69 & 0 \\
\hline
\end{tabular}

\subsection{In your work do you use any of the tools?}

There were very few or no answers to this question, which points to the fact that the municipalities, still, in practice, do not use modern tools or that they are used in a very small, inadequate measure. In the Municipality of Zavidovići the largest number of respondents use statistical process control (9 or $45 \%$ ), brainstorming ( 5 or $25 \%$ ), histogram (3 or $15 \%$ ), while a flow chart diagram and interrelationship diagram form an arrow by one respondent or $5 \%$.

In the Municipality of Kakanj equal number of respondents uses statistical process control and brainstorming, 5 or $27,78 \%$, while the flow chart, examination sheet, interrelationship diagram and system diagram are used by 2 respondents or $11,11 \%$.

In the Municipality of Žepče the largest number of respondents said that they used statistical process control 10 respondents, or $66,67 \%$, brainstorming 5 or $33,33 \%$,

In the municipality of Vareš most respondents answered that they used statistical process control - 6 respondents, or $46,15 \%$, brainstorming 3 or $23,08 \%$, examination sheet 2 or $15,38 \%$, a matrix chart and map software for processes 1 respondent or 7,69\%.

\section{Conclusions}

Given these considerations we can draw the following conclusions:

- Public administration is an important place where there are many things that occur and are resolved in direct contact with the citizens (customers) and where there is very quickly a feeling of pleasure or opposite to it,

- The system of public administration in Bosnia and Herzegovina is very complex and differs in some parts, with regard to the organization of the state.

- Through research on the sample of 5 municipalities in the same canton, we have tried to demonstrate and identify the perception of employees regarding the introduced quality system, through a number of questions and through transactions which they are faced with.

- In the four municipalities that have introduced the system, it is significant that among the majority of respondents there is a lack of information or confusion about the standards adopted.
- The training, which concerns not only the quality system, is performed rarely, with a fact that in the municipality of Kakanj there were trainings mostly in the field of quality management.

- The Municipality Kakanj has the best result (72,22 $\%)$ at the question of mutual respect and openness, which indicates the level of organizational culture, but the answers to the question of orientation of users indicate survival of bureaucratic approach to the methods of work, which stubbornly resists to changes in attitude and work rituals.

- In regards to the motivation of the employees, again the best results were achieved in the Municipality of Kakanj (with the Municipality of Žepče, at this question), the largest number of respondents compared to other municipalities $(33,33 \%)$ answered that they received rewards for jobs well done.

- Customer Satisfaction Surveys were not conducted regularly in any of the tested municipalities.

- When it comes to the tools of quality it is noticeable that there are used only some of the tools, with the fact that certain tools - statistical process control and brainstorming tools - are the tools chosen by the largest number of respondents in all tested municipalities.

Certainly, some of these things are consequences of the earlier system in which municipalities operated and will need to change and one of the ways is certainly the construction of quality system and its consistent application and improvement in the units of local selfgovernment (municipalities). The central feature of the quality management system is the notion of change of culture embedded in the theory and practice of quality management. The goal is to change the standpoint of management and employees towards quality culture. Part of the change in culture through the quality system is to achieve the transformation of people's standpoints toward the work they perform, as well as its role in the business.

\section{References}

[1] SIGMA izvještaj 2010: Procjena potencijalnih kandidata za članstvo u EU, str. 1, URL: http://www.parco.gov.ba, (20.03.2012)

[2] Bijela knjiga o transformaciji javnih usluga, 1997, str. 3, URL: http://www.dei.gov.ba, (21.03.2013) 
[3] Tuchman, A. The yellow brick road: Total quality management and the restructuring of organizational culture. Organizational Studies. 1994, pp. 728 (prilagođeno) https://doi.org/10.1177/017084069401500505

[4] Koprić, I. Mjere za modernizaciju uprave za Republiku Hrvatsku. // Informator, Novi informator, Zagreb, No 5298 (2004), pp. 1-3.

[5] Ustav Bosne i Hercegovine, član III. 3.6., URL: http://http:www.parlament.ba (21.03.2013)

[6] Ustav Bosne i Hercegovine, član 1.2. i dio člana II.2., URL: http://http:www.parlament.ba (21.03.2013)

[7] Bertram, D. The role of junior and middle level management in TQM, Hertfordshire, Technical Communications Ltd., 1993.

[8] Brysland, A.; Curry, A. Service improvements in public services using SERQUAL. // Managing service Quality. 11, 6(2001), pp. 391. https://doi.org/10.1108/09604520110410601

[9] Curry, A.; Herbert, D. Continuous improvement in public service - a way forward. // Managing Service Quality. 8, 5(1998), pp. 339-349. https://doi.org/10.1108/09604529810235079

[10] Pollit, C.; Bouckaert, G. Quality Improvement in European Public Services, London, Sage publications 1995.

[11] Marko, P. Uvođenje Total Quality Managementa u jedinicama lokalne samouprave i organizacijske promjene, Cleveland State University, Unger Croatia Program, 2001, pp. 13-15 (adopted by authors)

[12] Couper, D. Quality Improvement and Government, URL: http://deming.eng.clemson.edu/govt/ (30.03.2014)

[13] Filipović, J.; Đurić, M. Sistem menadžmenta kvaliteta, FON, Beograd, 2010.

[14] Vidanović, I. Rečnik socijalnog rada, Tiro-erc, Beograd, 2006.

[15] Pollit, C.; Bouckaert, G. Quality Improvement in European Public Services, Concepsts, Cases, Commentaries, Sage Publications, London, 1995, pp. 3-10.

[16] Kettl, D.; Dilulio, F.; John, J. Inside the Reinvention Machine: Appraising Governmental Reform, Brookings Institutions, Washington, 1995, pp. 48

[17] Sisek, B. Stakeholderski pristup i sustav kvalitete. // Revija za pravo i ekonomiju, Mostar. 2, (2004), pp. 53.

[18] Jašarević, S.; Miličević, Dž. Sistem kvaliteta i organizacione kulture u jedinicama lokalne samouprave, Naučna monografija, Univerzitet u Zenici, 2016.

\title{
Authors' addresses
}

\author{
Sabahudin Jašarević, Assoc. Prof. Ph.D. (contact author) \\ Samir Lemeš, Assoc. Prof. Ph.D. \\ Safet Brdarevic, Professor emeritus, \\ University of Zenica \\ Faculty of Mechanical Engineering \\ Fakultetska 1, 72000 Zenica, Bosnia and Herzegovina \\ E-mail: sjasarevic@mf.unze.ba
}

\section{Džeraldin Miličević}

Municipality of Zavidovići

Department for Administration of Economy and Entrepreneurship

Mehmed-paše Sokolovića bb, 72220 Zavidovići,

Bosnia and Herzegovina

E-mail: dzeraldina.milicevic@gmail.com 